\title{
Factors affecting the conservation and regeneration of the urban fabric of old cities: case study of Old Alexandria
}

\author{
K. Abdelhady \\ Department of Architecture, Faculty of Engineering, \\ Benha University, Egypt
}

\begin{abstract}
The archaeological sites in the heritage cities in Egypt suffer from informal settlements due to the population increase and lack of standardization of urban design and historic preservation of these areas. They also suffer from the illegal architectural additions in and around the archaeological sites that affected the view and the general effect on visitors, the unique spirit of place and affected also the cultural value of the monuments.

Alexandria is one of the most famous heritage cities in the world. It was founded around a small pharaonic town $(331 \mathrm{BC})$ by Alexander the Great. It remained Egypt's capital for nearly a thousand years, until the Muslims conquest of Egypt in (641 AD) when a new capital was founded at Fustat, which absorbed later into Cairo. The urban fabric of Alexandria contains many land marks of the archaeological sites such as "Pompey's Pillar" which is one of the best-known ancient monuments still existing in Alexandria today, "Alexandria's catacombs", which are known as Kom al-Soqqafa, are at short distance southwest of the pillar, consisting of a multi-level labyrinth, reached via a large spiral staircase, and the "Romanic theatre"[1].

In this paper we present a survey of the factors affecting the urban conservation and regeneration of the urban fabric of the old cities that the archaeological sites in Alexandria suffer from and aim to highlight the problems causing the urban fabric of the Alexandria the heritage city to lose its cultural essence. It aims also to assist making a framework for a sustainable plan for the development of the urban areas around the archaeological sites for the benefit of the inhabitants of these areas and for preserving the heritage value. This is concluded by suggesting a criteria for the decision makers to set processes that must occur through urban preservation and contemporary innovative designs for
\end{abstract}


the surrounding areas of the archaeological sites for preserving the soul of the urban palimpsest.

Keywords: preservation, informal settlements, archaeological sites, urban palimpsest, distinctive, urban rites and rituals.

\section{Introduction}

Alexandria was known because of its lighthouse (Pharaohs), one of the Seven Wonders of the Ancient World; its library (the largest library in the ancient world); and the Catacombs of Kom el Shoqafa.

Alexandria was founded by Alexander in April (331 BC) Alexander's chief architect for the project was Dinocrates. Alexandria was intended to supersede Naucratis as a Hellenistic centre in Egypt, and to be the link between Greece and the rich Nile Valley. An Egyptian city, Rhakotis, already existed on the shore, and later gave its name to Alexandria in the Egyptian language (Egypt. Ra'qedyet). It continued to exist as the Egyptian quarter of the city. A few months after the foundation, Alexander left Egypt to the east and never returned to his city. After Alexander departed, his viceroy Cleomenes continued the expansion. Following a struggle with the other successors of Alexander, his general Ptolemy succeeded in bringing Alexander's body to Alexandria.

Very little of the ancient city has survived into the present day. Much of the royal and civic quarters sank beneath the harbour due to earthquake subsidence, and the rest has been built over in modern time's viceroy [1].

Since the great and growing modern city stands immediately over the ancient one, it is almost impossible to find any considerable space in which to dig, except at enormous cost. Also, the general subsidence of the coast has submerged the lower-lying parts of the ancient town under water. This underwater section, containing many of the most interesting sections of the

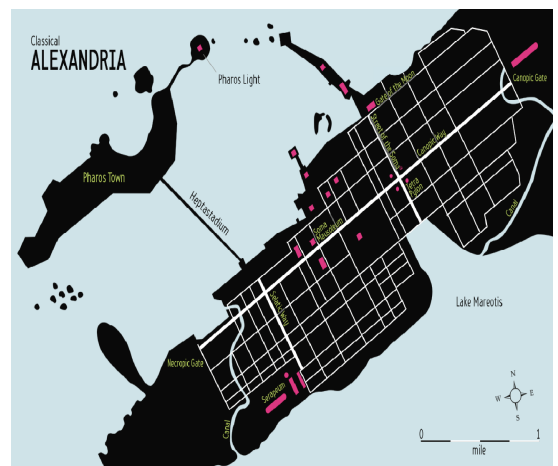

Figure 1: Old Alexandria map before the earthquake [1].

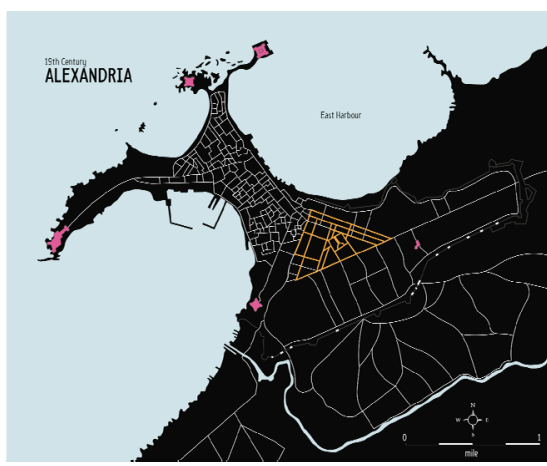

Figure 2: 19th century Alexandria map after the earthquake [1]. 
Hellenistic city, including the palace quarter, is still being extensively investigated by the French underwater archaeologist Franck Goddio and his team. It raised a noted head of Caesarian. These are being opened up to tourists, to some debate. The spaces that are most open are the low grounds to northeast and southwest, where it is practically impossible to get below the Roman strata [2].

\section{Layout of the ancient city}

Greek Alexandria was divided into three regions:

\subsection{Brucheum}

The Royal or Greek quarter, forming the most magnificent portion of the city. In Roman times Brachium was enlarged by the addition of an official quarter, making four regions in all. The city was laid out as a grid of parallel streets, each of which had an attendant subterranean canal.

\subsection{The Jewish quarter}

This forms the northeast portion of the city.

\subsection{Rhakotis}

The old city of Rhakotis, the work area of this paper, has been absorbed into Alexandria. It was occupied chiefly by Egyptians (From Coptic "Alexandria").

Two main streets, lined with colonnades and said to have been each about 60 meters wide, intersecting in the centre of the city, close to the point where the Soma of Alexander (his Mausoleum) rose. This point is very near the present mosque of Nabi Daniel; and the line of the great East-West "Canopy" street, only slightly diverged from that of the modern Boulevard de Rosette (now Sharia Fouad).

\section{Ancient remains}

\section{1 "Pompey's Pillar"}

This is one of the best-known ancient monuments still existing in Alexandria today. It is located on Alexandria's ancient acropolis - a modest hill located adjacent to the city's Arab cemetery - and was originally part of a temple colonnade. Including its pedestal, it is $30 \mathrm{~m}$ high; the shaft is of polished red granite, 2.7 meters in diameter at the base, tapering to 2.4 meters at the top. The shaft is 36 meters made out of a single piece of granite. This would be 132 cubic meters or approximately 396 tons. Pompey's Pillar may have been erected using the same methods that were used to erect the ancient obelisks. 
"Pompey's Pillar" is a misnomer, as it has nothing to do with having been erected in (293 AD) for Diocletian, possibly in memory of the rebellion of Domitius Domitianus. Beneath the acropolis itself are the bottomless remains of the Serapeum, where the mysteries of the god Serapis were enacted, and whose carved wall niches are believed to have provided overflow storage space for the ancient Library [1].

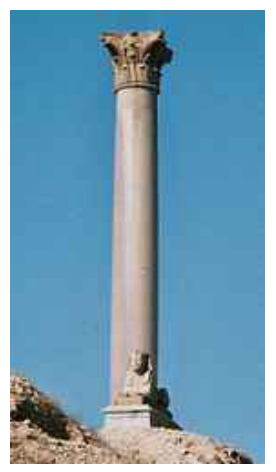

Figure 3: Pompeys Pillar.

\subsection{Kom al-Dikka}

The German excavation team found remains of a Ptolemaic colonnade and streets in the north-east of the city, but little else. Hogarth explored part of an immense brick structure under the mound of Kom al-Dikka, which may have been part of the Roman fortress.

The making of the new foreshore led to the dredging up of remains of the Patriarchal Church; and the foundations of modern buildings are rarely laid without some objects of antiquity being discovered. The wealth underground is doubtlessly gigantic; but despite all efforts, there is not much for antiquarians to see in Alexandria outside the museum and the neighbourhood of "Pompey's Pillar". The native tomb-robbers, well-sinkers, dredgers, and the like, however, come upon valuable objects from time to time, most of which find their way into private collections.

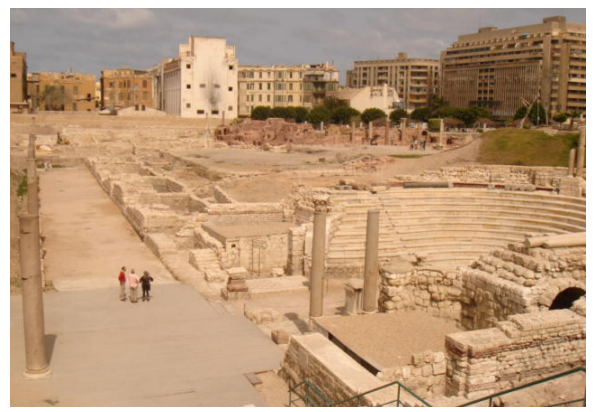

Figure 4: Kom al-Dikka. 


\subsection{Catacombs}

Alexandria's catacombs, known as Kom al-Soqqafa, are a short distance southwest of the pillar, consist of a multi-level labyrinth, reached via a large spiral staircase, and featuring dozens of chambers decorated with sculpted pillars, statues, and other syncretic Romano-Egyptian religious symbols, burial niches and sarcophagi, as well as a large Roman-style banquet room, where memorial meals were conducted by relatives of the deceased. The catacombs were long forgotten by the citizens until they were discovered by accident in the $1800 \mathrm{~s}[1]$.

\section{Layout of the city now}

Alexandria had a rapid growth process now, and it's done without standardization of urban design and historic preservation.

Table 1, the comparison between the growth process of old Alexandria from classic era and the 19th century, indicate the gradual growth going on.

Table 1: Comparison between the classic era and 19th century for the growth process of Alexandria's urban fabric [2].

\begin{tabular}{|l|l|l|}
\hline Unit of analysis & classic era & 19 th century \\
\hline Total area (square meters) & $1,307,000$ & $4,113,000$ \\
\hline Sum of length of all street segments & 66,608 & 67,521 \\
\hline Number of street segments & 301 & 415 \\
\hline Average length of street segments & 221 & 163 \\
\hline Shortest street segment (meters) & 14 & 8 \\
\hline Longest street segment (meters) & 1,859 & 2,491 \\
\hline
\end{tabular}

In present day, Alexandria extends about $32 \mathrm{~km}$ along the coast of the Mediterranean Sea and its area about: $2,679 \mathrm{~km}^{2}$ with a population of 4.1 million. We cannot calculate the length of all streets, number of streets and the average length of the city and its extension toward the west and the east north cost. The southern boundaries also now overlapped with the nearest small towns. We can now know how the growth is continuing.

To highlight the problems that the urban fabric of the Old Alexandria the heritage city suffer from, a survey of facts and studies behind the informal settlements which the archaeological sites suffer from had been completed.

\section{Examples for the informal settlements built in and around the archaeological sites}

There are many architectural editions to the archaeological sites such as buildings for offices, facilities, security and fences built in the archaeological area and another informal settlements around the bounders of the sites such as temporary shops and furthermore the residential high-rise buildings all around. 
The research records the trespasses in the study areas as follows.

\subsection{Amoud el-sawary "Pompey's Pillar"}

There are new graveyards built on a big sector of the archaeological site, part of the monuments, masonry walls, tunnels and columns disappeared under the new tombs and fences.

The main axis to the site is very crowded and full of illegal hawkers, which affects the view and the vision of the site.

There are many residential high-rise buildings all around.
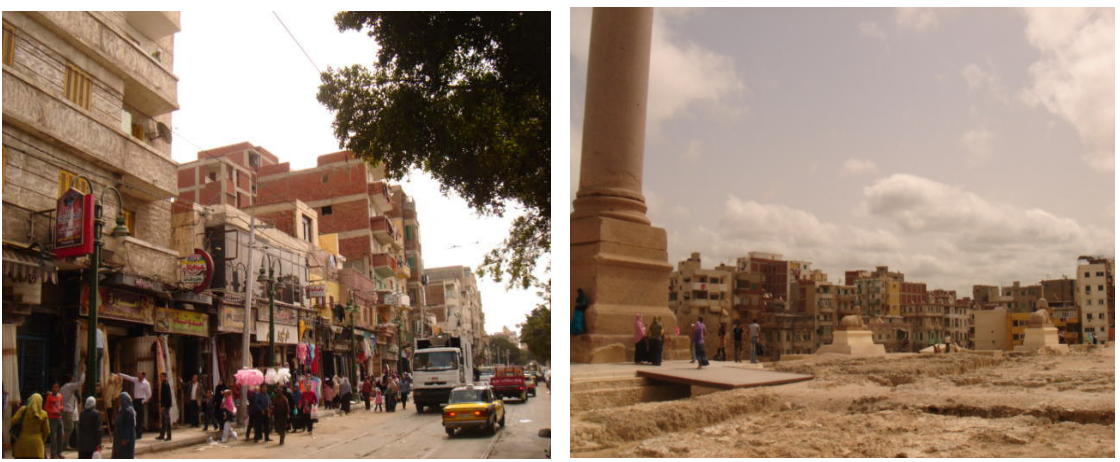

Figure 5: "Pompey’s Pillar" and the surrounding area.

\subsection{Kom al-Dikka, "Romanic theatre"}

There are many buildings for offices, facilities, security and fences built in the sit and at the pounders, a fire fitting station was built and furthermore a new amphitheater built next to the archaeological one, it was built in different materials (sandstone).
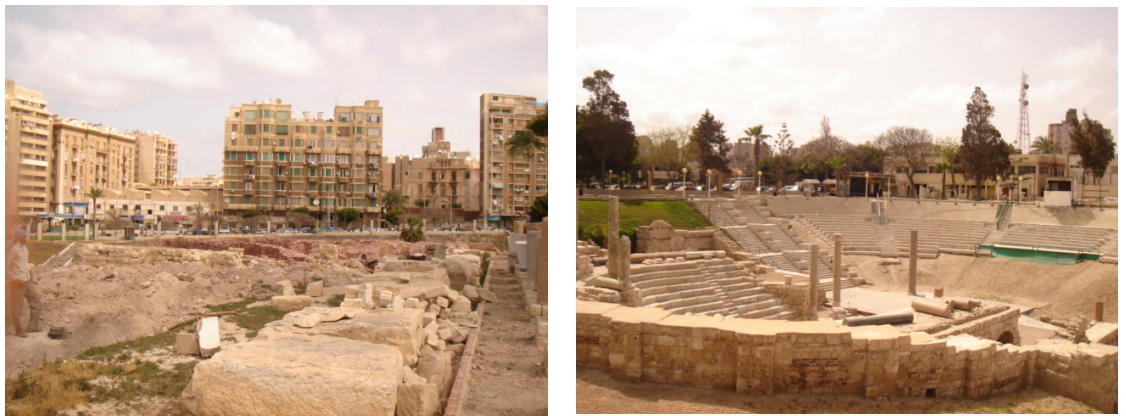

Figure 6: "Romanic theatre" and the area around it. 


\subsection{Kom al-shoaafa "Catacombs"}

There are many residential, high-rise buildings surrounding the site so; no one can see the site until being inside the archaeological site.
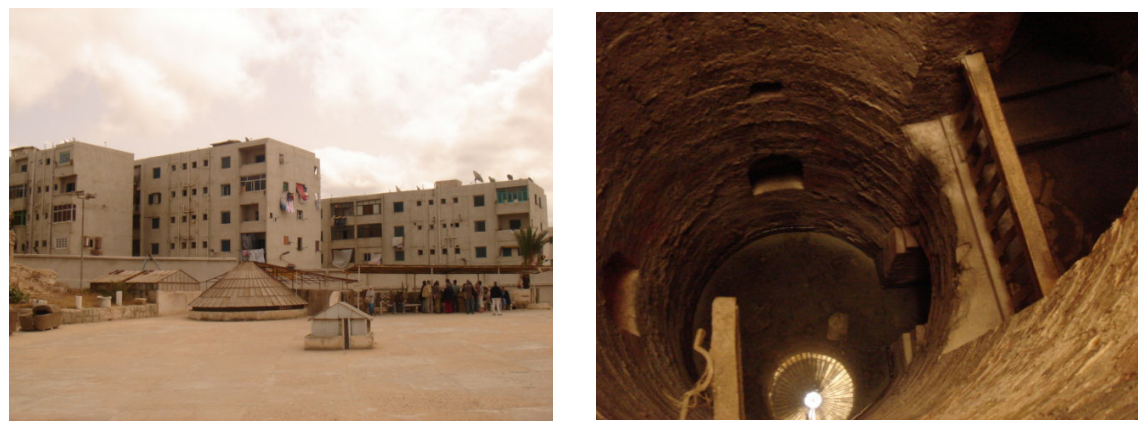

Figure 7: "Catacombs" and the area around it.

The underground water level is so high due to the high occupations and the corrupt drain systems, so; three floors of the archaeological tomb sinking in the ground water and this is the main factor affecting the deterioration of the tombs.

\section{The negative urban effects of the archaeological sites}

\subsection{The visual pollution for the archaeological panorama}

The visual pollution is classified into two types:

- Static visual pollution: It's a non-appropriative change in the archaeological site environment which consists of: the new buildings in the sites, the background, the main axis to the site and the sites boundaries.

The main factors causing static visual pollution are: the new informal settlements surrounding the site which affect the panorama.

- Dynamic visual pollution: The movement of the vehicles, the moving hawker and the lights of advertising illuminating and surrounding the sites, affecting the visitor's vision and affecting the sensory impact of the heritage value [4].

\subsection{The approach and the archaeological site vision}

The existing actual case of the case studies, reflect that no one can see appropriate approach to the sites and feel the heritage value, this is because there is no enough free area around the site as an adytum to the site, (protectorate area). So the sudden transfer from the crowded noisy area to the archaeological site affect the sense of heritage value. 


\subsection{The new buildings in the archaeological site}

The new buildings, built for the benefit of tourism or other facilities such as the new amphitheatre built in the front of the archaeological one for the festivals creation to benefit from the archaeological background, the trespasses of the graveyard area built on a big sector of the Pompey's Pillar and all those trespasses causes damages to the archaeological sites, such as:

- Hiding the archaeological elements.

- Impede excavation process.

- Changing the archaeological environment by using new materials.

\section{Properties of the cultural value districts in the heritage cites in Egypt}

\subsection{Urban properties}

The sites that have a cultural and historical value mostly have lack of infrastructure networks and the services do not satisfy the needs of the inhabitants.

In the last few decades gardens and open spaces were informal settlements for the poor hawker so that they can benefit from the visitors of the archaeological sites, this led to a change in the social structure in these sites and affected their infrastructure.

\subsection{Economic properties}

The cultural sites in Egypt are characterized with the presence of various traditional crafts that each mostly occupies a whole area.

Also the lack of sufficient funds affects the urban and archaeological cultural projects in these areas.

\subsection{Social properties}

Successive cultures in the cultural sites affect the behaviour of the society and its traditions, this gives the society some distinguished characteristics, and these traditions in return affect the successive stages of the cultural cities development.

There have been several demographic and social changes in the cultural sites especially in the last few decades, as their original inhabitants (upper class, scientists and businessmen) were replaced by new low-income inhabitants searching for a job opportunity through selling things to the visitors of the archaeological sites [5].

\section{Preserving the soul of the urban fabric of the heritage cites}

All the conservation projects of the archaeological sites in Egypt deal only with the monuments, masonry walls and the archaeological remains, and usually do not deal with the axis roads to the sites and the interaction between the urban 
surrounding and the archaeological sites. So as a result the urban fabric loses its soul.

Preservation of the archaeological sites alone is not sufficient, it should extend to preserve the urban surrounding of the sites and also extend to the main axis connecting the nearest archaeological sites and deal with all as a one unit.

Figs 8 and 9 present Vatican urban surrounding and the soul of urban fabric heritage city, and the disharmony between the Romanic theatre and its urban surrounding.

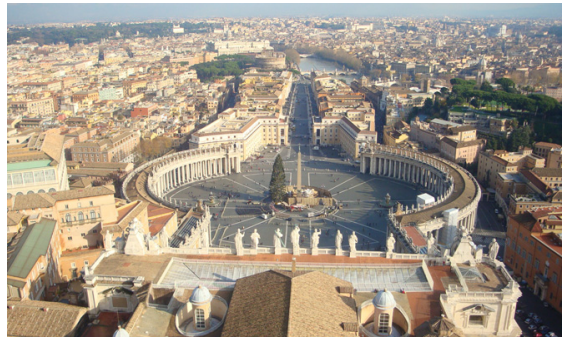

Figure 8: Vatican the soul of the urban fabric.

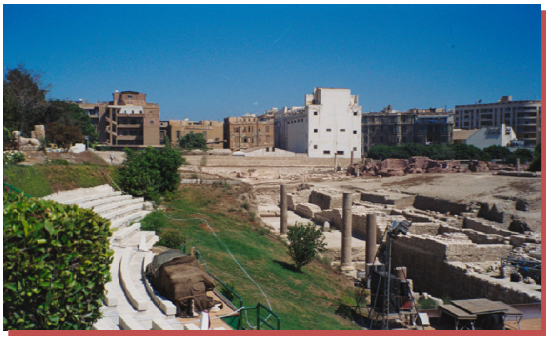

Figure 9: "Romanic theatre" and the area around it.

\section{Heritage $=$ distinctive spirit/soul.}

\section{Soul $=$ collective memory .}

Archaeological sites are traces that remain as marks inherited from the past that gradually evolve into heritage [2]. The Coliseum gradually became a part of the urban fabric of Rome the heritage city (see fig. 10).

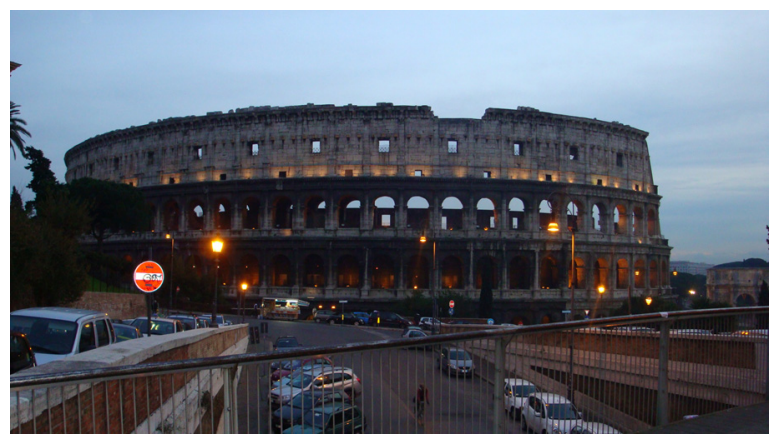

Figure 10: Coliseum, well-known archaeological site in Rome.

The methodology of urban preservation of the heritage cities started by:

- Recording the townscape through: Street network, Plots, Building footprints.

- $\quad$ Recording the significant historical buildings and sites and historicist designs. 


\section{To extend beyond physical elements}

- Urban preservation:

- Balances the symbolic significance of intangible and tangible heritage.

- Contemporary innovative designs.

- Urban rites and rituals:

- Bind residents.

- Establish continuity.

- 'Localized' urban landscapes:

- Contemporary.

- Distinctive spirit of place.

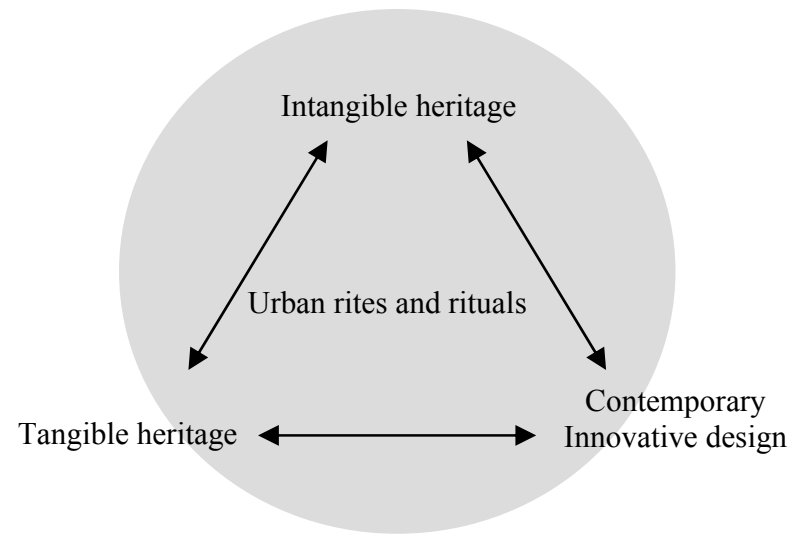

Figure 11: The relationship between the factors affecting the urban preservation of the heritage cities.

To preserve the soul of the urban fabric of the heritage cities we should make a standardization of urban design compatible with the feature of the archaeological sites taking into consideration the existing integral urban system which contains:

- The environment.

- Architecture.

- Human aspects.

- Socio-economic requirements.

After that we can start historic preservation.

Through studying the elements of the comprehensive urban system, we can find out that there are complex relations affecting the urban features of cultural and historical values.

Urban preservation should be in long term steps, because we cannot do all the needs of socio-economic requirements, and changing the human aspect in one step. So; the main plan of the urban preservation should contain gradual solutions to deal with urgent problems. 


\section{Conclusion}

To preserve the soul of the urban fabric of the heritage cities we should make a standardization of urban design compatible with the feature of the archaeological sites taking in consideration the existing integral urban systems.

The parameters and the framework for a sustainable plan should take into consideration the balances in the symbolic significance of intangible and tangible heritage, the urban rites and rituals and the distinctive spirit of place.

\section{Recommendations}

- The comprehensive preservation methodology should follow in the development sustainable urban plan of the districts which have a heritage value.

- We should make a documentation system to record the significant historical buildings and historicist designs in heritage cities.

- The archaeological sites and the historic feature observed and recorded, and all the studies of the sites should be references to the sustainable conservation development plan.

- The development sustainable urban plan should define an integrated vision to the districts and the urban surrounding of the archaeological sites.

- Controlling the new buildings in the archaeological sites, and if it is necessary it should be temporary and without affecting the archaeological sites features and heritage value.

- Start making new roles to control the informal settlements in the heritage cities.

- Defining the protectorate area of the archaeological sites.

\section{References}

[1] Supreme Council of Antiques, Cairo Egypt, Documentation of Old Alexandria 2010.

[2] Luna Khirfan, Traces on the Palimpsest: Heritage and the Urban Forms of Athens and Alexandria, The University of Waterloo: WECMES conference 2010 .

[3] N. Ashry, Employing technology in urban planning of the archaeological sites in Egypt, El-Behera Conference 2003.

[4] K Abdelhady, The reuse of the urban surrounding of the archaeological sites in Egypt, El-faiom international Conference 2006.

[5] M. Abdalah, The increase of protection limit for the monuments international charters, El-Azhar international Conference 2000. 